\title{
Emission of Methane from Dead Trees / Snags of Tropical and Sub- Tropical Forest Ecoregions
}

\author{
A. Muthu Kumar ${ }^{1 *}$, R. Ezhumalai ${ }^{2}$, A. K. Pandey ${ }^{3}$ and M. Srinivasa Rao ${ }^{4}$ \\ ${ }^{1}$ Department of Forest Protection, Institute of Wood Science and Technology, 18th Cross, \\ Malleshwaram, Bangalore - 560003, Karnataka, India \\ ${ }^{2}$ Department of Timber Mechanics, Forest Research Institute, Dehradun, India \\ ${ }^{3}$ Alkem Health Science Ltd., Sikkim, India \\ ${ }^{4}$ Chief General Manager (Planning), FDCM, Maharashtra, India \\ *Corresponding author
}

Keywords

Methane flux, Decay trees; Tropical forests; Western Ghats; Global warming

Article Info

Accepted: 12 April 2021 Available Online: 10 May 2021
Methane emission from various sources of biosphere contributes to the global warming/climate change related problems. Methane release from standing dead or age old trees, a new-fangled source for emission of $\mathrm{CH} 4$, was investigated. The experiment was carried out in tropical and subtropical forest ecoregions of Western Ghats of India. A standardized protocol was formulated for sampling and analysis of the gas samples collected from dead/decay trees. Based on our standardized protocol maximum and minimum emission of $\mathrm{CH} 4$ concentration was recorded. The result confirms that dead trees in forests release significant quantity of methane and henceforth could be another source contributing to global warming. Our data suggest that the average methane emission from dead trees of Rosewood (Dalbergia latifolia) was 1949.89 ppm, Matti (Terminalia tomentosa) was $4630.36 \mathrm{ppm}$, Teak (Tectona grandis) was $1561.92 \mathrm{ppm}$ and Shisham (Dalbergia sisso) was 3059.45 ppm.

\section{Introduction}

Methane (CH4) is the second most important anthropogenic greenhouse gas. Methane plays an important role in the chemical and radioactive balances in the Earth's atmosphere, predominant source of water vapour (Jones and Pyle, 1984), and is the primary sink for chlorine radicals (Cicerone and Ordmland, 1988). The global warming potential (GWP) of $\mathrm{CH} 4$ is 28 over a time horizon of 100 years (Myhre et al., 2013). Methane is 
released into the atmosphere, from both anthropogenic and natural sources (Patra et al., 2011; Kirschke et al., 2013). The present day concentration of $\mathrm{CH} 4(\sim 1800 \mathrm{ppb})$ is unprecedented over at least the past 800, 000 years (Loulergue et al., 2008).

Measurements of $\mathrm{CH} 4$ in air bubbles trapped in Antarctic and Greenland ice sheets suggest that after a very slow increase (average rate of $~ 0.04 \mathrm{ppb}$ yr-1) during pre-industrial time (1-1750 AD), $\mathrm{CH} 4$ concentration have increased rapidly (average rate of $\sim 4 \mathrm{ppb}$ yr- 1 during 1750-1990 AD) until the early 1990s (Rasmussen and Khalil, 1984; Etheridge et al., 1998; Nakazawa et al., 1993; MacFarling Meure et al., 2006). The rapid rise of $\mathrm{CH} 4$ levels paused in the 1990s (Dlugokencky et al., 2003) and resumed strong growth starting in 2007 (Rigby et al., 2008; Dlugokencky et al., 2009).

Early in 2006, Keppler et al., (2006) reported measurements that implied plants produced methane in aerobic condition, and that the fluxes were approx. $10-45 \%$ of the total global methane source. This implies either that the classical methanogenic pathway operates under aerobic conditions or has gone undetected in plants. A novel phenomenon has been found in some bacteria, where methane is a byproduct of methylophosphonate decomposition (Karl et al., 2008).

Forest is the world's most important and most valuable renewable natural resource and also repositories of terrestrial biodiversity. This resource is facing serious threats due to abiotic and biotic stresses resulting from urban expansion, infrastructure development and agriculture and global warming (Bawa and Dayanandan, 1998).

In the forest, decay trees may be significant new source of methane that contribute to climate change, said Kristofer Covey, researcher at Yale School of Forestry and Environment Studies. The study was carried out at Yale Myers Forest in northeastern Connecticut.

According to the Covey et al., (2012) methane concentration release from decay trees were as high as 80,000 times ambient levels and found average levels of 15,000 parts per million inside trees.

The report of Covey et al., (2012) concluded methane release from tropical dead forest has to be studied for understanding the comprehensive release of methane from various sources of this world. We had worked in tropical and sub-tropical forests from the state of Karnataka, India for understanding methane flux contribution.

\section{Materials and Methods}

\section{Selection of study area}

Five different location of Karnataka state where selected based on agro climatic zones viz., Northern dry zone (Dharwad), Coastal zone (Kundapura Forest Division), Southern transition zone (Kudremukh National Park), Hilly zone (Ponnampet) and Eastern dry zone (Institute of Wood Science and Technology IWST Campus).

\section{Selection of trees}

The selected tree species include dead trees / snags standing at different sampling locations as mentioned above at 2.1. The tree species we had encountered during our study were Poeciloneuron indicum (Balige), Elaecarpus tuberculatus (Kunge Mara), Carallia brachiata (Andipunar), Dalbergia sissoo (Indian Rosewood), Terminalia tomentosa (Matthi), Tectona grandis (Teakwood), Dalbergia sissoo (Shisham) and Anogeissus latifolia (Dindiga). 


\section{Sampling methods}

The gas samples were collected based on the methodology adopted by Covey et al., (2012), which includes;

Trees were drilled at chest height $(1.3 \mathrm{~m})$ with $5 / 16$ " drill bit and immediately plugged with a stopper of appropriate size.

After that $50 \mathrm{ml}$ syringe was inserted through the stopper into the cavity to remove $50 \mathrm{ml}$ trunk gas from each tree and store into a vacuum sealed sample vials for GC analysis.

Steps standardized for trunk gas sampling in our study

Trees were drilled horizontally at chest height to mid portion of the trunk with a $12 \mathrm{~mm}$ drill bit and immediately plugged with a 14 mm stopper.

Incubation period: $2 \mathrm{hrs} / 4 \mathrm{hrs} / 6 \mathrm{hrs} / 12 \mathrm{hrs} /$ 24hrs.

A $20 \mathrm{ml}$ gas syringe was inserted through the stopper into the cavity to remove $20 \mathrm{ml}$ of trunk gas from each tree.

Then trunk gas samples were stored into an anaerobic gas chromatography vials for further laboratory analysis.

Gas Chromatography (GC) analysis of collected methane sample

The trunk gas methane concentration was analyzed by a gas chromatography with FID (flame ionization detector). The gas concentrations were represented in $\mathrm{ppm}$. The procedure for GC analysis is described below.

Prepare the standard samples for calibration and set the parameters

Oven temperature $=60^{\circ} \mathrm{C}$
FID temperature $=350^{\circ} \mathrm{C}$

Carrier gas pressure $=4 \mathrm{~kg}(\mathrm{~N} 2), 2 \mathrm{~kg}(\mathrm{O} 2), 2 \mathrm{~kg}$ (He)

After set the parameter, GC was calibrated by inject standard samples containing varying concentrations of the compound to be analyzed and creating a calibration curve

Then trunk gas sample was injected into the carrier gas stream by inserting the needle of a special expensive syringe through a heavy wall rubber septum of gas sample vials.

After all the peaks attained stop the run and get results

The retention time for methane was near to $1.2 \mathrm{~min}$. The methane peak usually comes of within a few minutes after $\mathrm{CO}$ peak. Peak area counts for each sample and compared with a calibration standard curve

After that calculate the calibration factor from standard, the amount of Methane (percent) in each sample calculate based on the calibration factor of standard

Observation and calculation of GC data

\section{Statistical Analysis}

SALSTAT 2 software was used for understanding the distribution of methane flux for all the selected tree species and their comparison using plot box and whisker graph.

\section{Results and Discussion}

\section{Tree species and geographical location}

The selected dead trees were old ranging between $80-90$ year's approximately, and the species involved were Poeciloneuron indicum (Balige), Elaecarpus tuberculatus (Kunge 
Mara), Carallia brachiata (Andipunar), Dalbergia sissoo (Indian Rosewood), Terminalia tomentosa (Matthi), Tectona grandis (Teakwood), Dalbergia sissoo (Shisham) and Anogeissus latifolia (Dindiga). The geographical locations are as follows (Tab. No.1).

The dead trees were selected based on visual tree assessment or symptoms expressed by the trees. Only dead trees were selected, partially dead trees were ignored. We had identified 10 numbers of dead trees of Poeciloneuron indicum and Elaecarpus tuberculatus from Kudremukh National Park for trunk sampling. The gas samples were collected from the trunk of the dead trees as suggested by Covey et al., (2012). The Gas Chromatography analysis of the samples from Kudremukh National Park revealed negative results, hence Covey method was modified, standardized and adopted (Materials \& Methods 2.4). Later, standardized method of trunk gas sampling was carried out at IWST Campus. Since the selected tree species was completely dead and only the snag was present, species identification was not possible. The species Carallia brachiata, was selected for the study purpose from Kundapura Forest Division spread along three different ranges viz Kundapura range, Sanker Narayana range, and Hebri range. The selected trees were completely dead. From hilly zone, we selected Ponnampet of Kodagu district for our study purpose, where we noticed age old Dalbergia sissoo and Terminalia tomentosa found to be stressed followed by decline. In our study the northern part of Karnataka was represented by the forest areas of Dharwad. Here we found different tree species of Tectona grandis, Terminalia tomentosa, Dalbergia sissoo and Anogeissus latifolia which were found dried and dead (Tab. No. 2). The selected trees for this study fall under different agroclimatic zones and they were almost dead due to interchangeable predisposing, inciting, and contributing factors.

\section{Gas Chromatography and Statistical Analysis}

The gas samples were analyzed using Gas Chromatography (Mayura Analytical Pvt. Ltd, Bangalore) as per the procedure stated in Materials and Methods 2.5. The distribution of methane flux of dead trees from IWST Campus was 78690 ppm with an incubation period of 24 hours, while the lowest emission was recorded as $20 \mathrm{ppm}$ with an incubation period of 2 hours (Fig. No.1).

The highest emission of $\mathrm{CH} 4$ was recorded in Carallia brachiata which was 38602 ppm (24 hours) and lowest was 277.985 ppm (2 hours). The methane flux data of Carallia brachiata was experimented during summer and winter season (Fig. No. 2 and 3).

Dalbergia sissoo from Ponnampet was recorded with highest $\mathrm{CH} 4$ emission of 5373 ppm (24 hours) and the lowest emission recorded was $84.08 \mathrm{ppm}$ (2 hours), while in Terminalia tomentosa the highest $\mathrm{CH} 4$ emission observed was 34540 ppm (24 hours) and the lowest recorded $432 \mathrm{ppm}$ (2 hours) (Fig. No. 4 and 5).

Tectona grandis from Dharwad region was recorded with maximum $\mathrm{CH} 4$ emission of 3456 ppm (24 hours) and the lowest emission recorded was $334.1 \mathrm{ppm}$ (2 hours). The trees of Anogeissus latifolia showed a maximum $\mathrm{CH} 4$ release of $9422 \mathrm{ppm}$ (24 hours) and the lowest emission recorded was $1.449 \mathrm{ppm}$ (2 hours). Terminalia tomentosa located at Dharwad emitted highest $\mathrm{CH} 4$ emission of $10120 \mathrm{ppm}$ (24 hours) and the lowest emission recorded was $175.7 \mathrm{ppm}$ ( 2 hours). 
Table.1 Geographical locations and tree species

\begin{tabular}{|c|c|c|}
\hline S. No. & Name of the tree species & Locations \\
\hline 1. & $\begin{array}{l}\text { Poeciloneuron indicum and Elaecarpus } \\
\text { tuberculatus }\end{array}$ & Kudremukh National Park \\
\hline 2. & Carallia brachiata & Kundapura Forest Division \\
\hline 3. & Dalbergia sissoo and Terminalia tomentosa & Ponnampet \\
\hline 4. & $\begin{array}{l}\text { Tectona grandis, Terminalia tomentosa, } \\
\text { Dalbergia sissoo and Anogeissus latifolia }\end{array}$ & Dharwad \\
\hline
\end{tabular}

Table.2 Characteristics and sample collection details from dead trees

\begin{tabular}{|c|c|c|c|c|c|c|}
\hline Latitude & Longitude & Tree Species & $\begin{array}{l}\text { Number } \\
\text { of dead } \\
\text { tree }\end{array}$ & $\begin{array}{l}\text { Canopy } \\
\text { height } \\
\text { (m) }\end{array}$ & $\begin{array}{c}\text { Samplin } \\
\text { g height } \\
\text { (m) }\end{array}$ & $\begin{array}{c}\text { Gas } \\
\text { quantity } \\
\text { taken }(\mathrm{ml})\end{array}$ \\
\hline \multicolumn{7}{|c|}{ Kudremukh National Park Forest region } \\
\hline \multirow[t]{2}{*}{$13^{\circ} 07^{\prime} 46.24^{\prime \prime} \mathrm{N}$} & \multirow[t]{2}{*}{$75^{\circ} 16^{\prime} 06.79^{\prime \prime} \mathrm{E}$} & $\begin{array}{l}\text { Poeciloneuron } \\
\text { indicum }\end{array}$ & 3 & \multirow[t]{2}{*}{29} & \multirow[t]{2}{*}{1.5} & \multirow[t]{2}{*}{20} \\
\hline & & $\begin{array}{l}\text { Elaecarpus } \\
\text { tuberculatus }\end{array}$ & 7 & & & \\
\hline \multicolumn{7}{|c|}{ IWST Campus Forest region } \\
\hline $13^{\circ} 0040.33 ” \mathrm{~N}$ & $77^{\circ} 3412.72 ” \mathrm{E}$ & - & 10 & 30 & 1.5 & 20 \\
\hline \multicolumn{7}{|c|}{ Kundapura Forest Division Forest region } \\
\hline $13^{\circ} 0040.33 ” N$ & $77^{\circ} 3412.72 ” \mathrm{E}$ & $\begin{array}{l}\text { Carallia } \\
\text { brachiata }\end{array}$ & 26 & 35 & 1.5 & 20 \\
\hline \multicolumn{7}{|c|}{ Ponnampet Forest region } \\
\hline \multirow[t]{2}{*}{$\begin{array}{c}12^{\circ} 08 ' 56.60^{\prime \prime} \\
\mathrm{N}\end{array}$} & \multirow[t]{2}{*}{$\begin{array}{c}75^{\circ} 56^{\prime} 25.86^{\prime \prime} \\
\mathrm{E}\end{array}$} & $\begin{array}{l}\text { Dalbergia } \\
\text { sissoo }\end{array}$ & 19 & 32 & 1.5 & 20 \\
\hline & & $\begin{array}{c}\text { Terminalia } \\
\text { tomentosa }\end{array}$ & 23 & 35 & 1.5 & 20 \\
\hline \multicolumn{7}{|c|}{ Dharwad Forest region } \\
\hline \multirow[t]{4}{*}{$15.3778^{\circ} \mathrm{N}$} & \multirow[t]{4}{*}{$75.2479^{\circ} \mathrm{E}$} & Tectona & 5 & 36 & 1.5 & 20 \\
\hline & & $\begin{array}{l}\text { Dalbergia } \\
\text { sissoo }\end{array}$ & 9 & 30 & 1.5 & 20 \\
\hline & & $\begin{array}{l}\text { Terminalia } \\
\text { tomentosa }\end{array}$ & 5 & 30 & 1.5 & 20 \\
\hline & & $\begin{array}{c}\text { Anogeissus } \\
\text { latifolia }\end{array}$ & 11 & 31 & 1.5 & 20 \\
\hline
\end{tabular}


Fig.1 Gas Chromatography data plotted showing distribution of methane flux in trees at IWST Campus

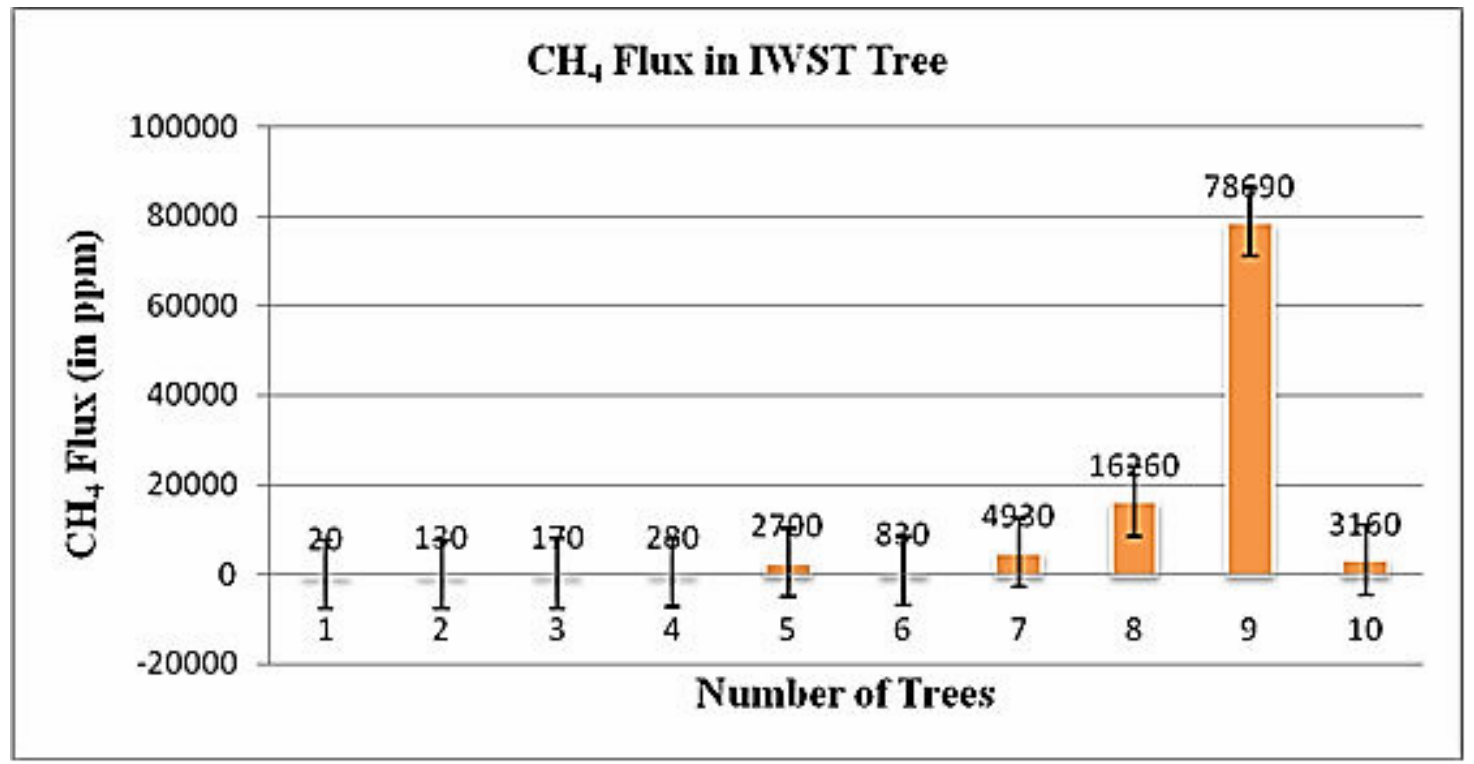

Fig.2 Gas Chromatography data plotted showing distribution of methane flux in Carallia brachiata during summer

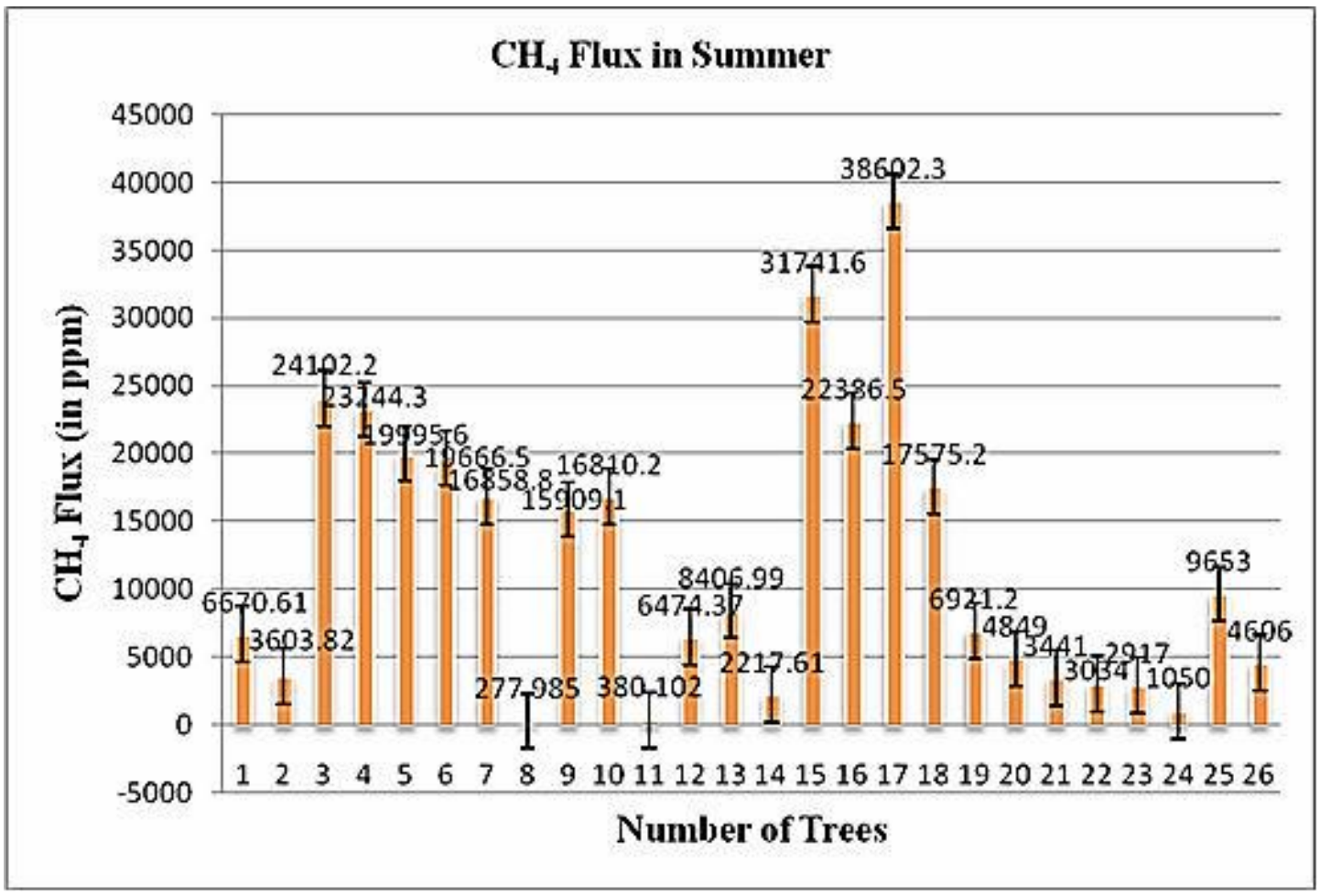


Fig.3 Gas Chromatography data plotted showing distribution of methane flux in Carallia brachiata during winter

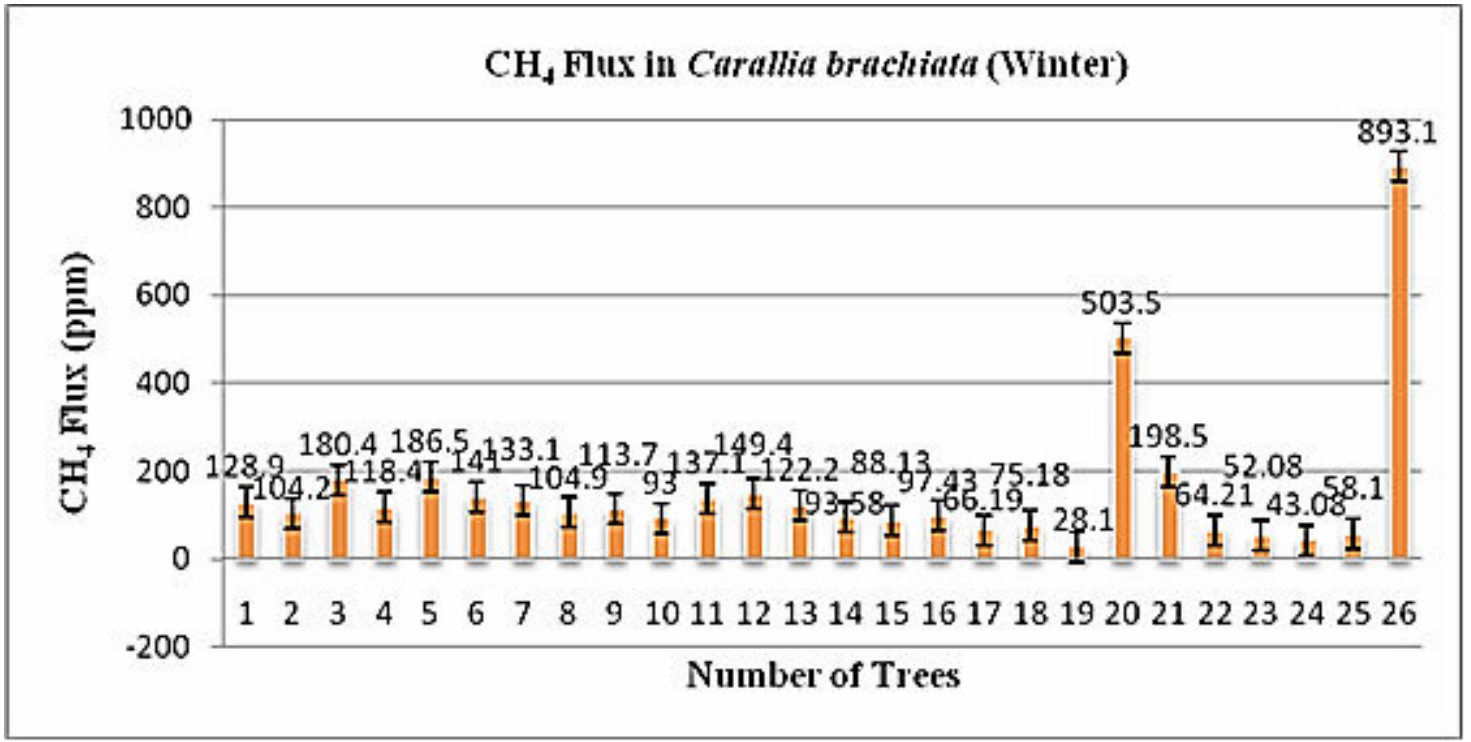

Fig.4 Gas Chromatography data plotted showing distribution of methane flux in Dalbergia sissoo

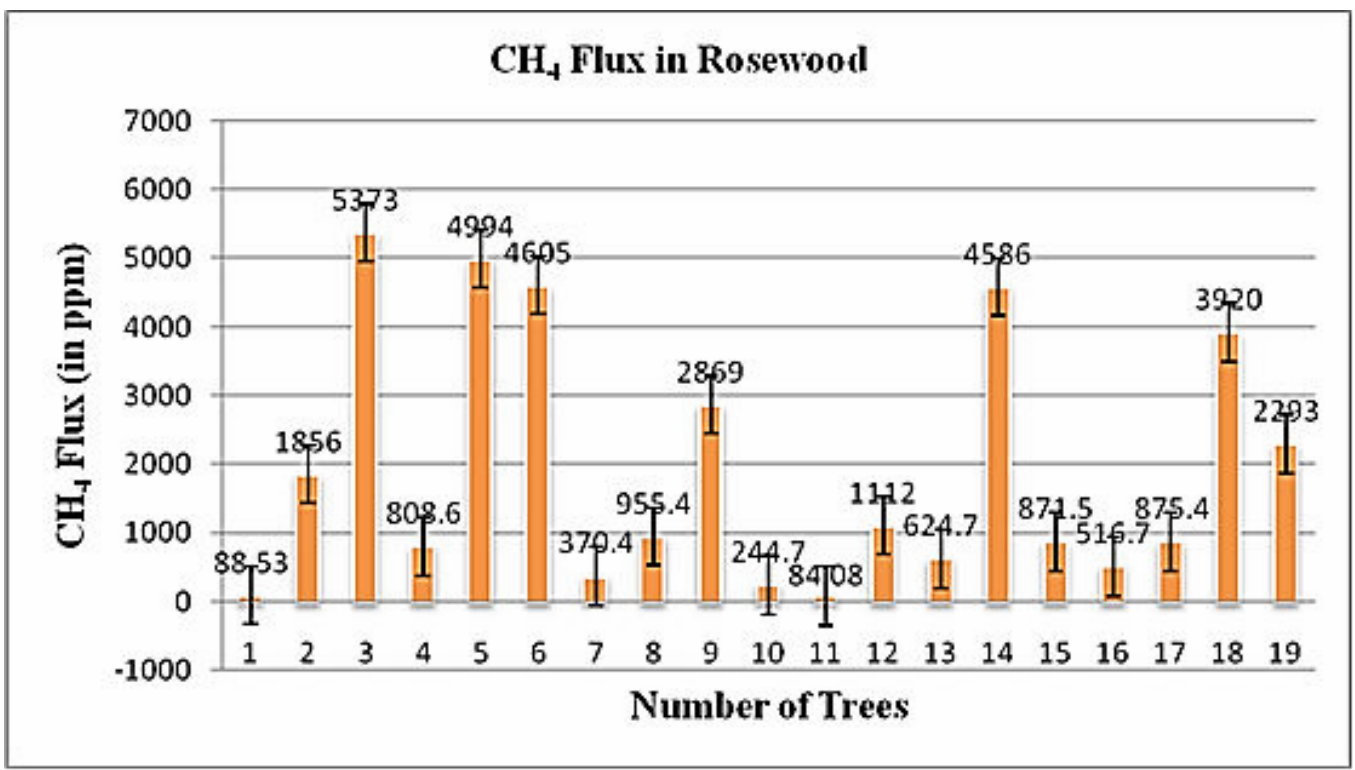


Fig.5 Gas Chromatography data plotted showing distribution of methane flux in Terminalia tomentosa

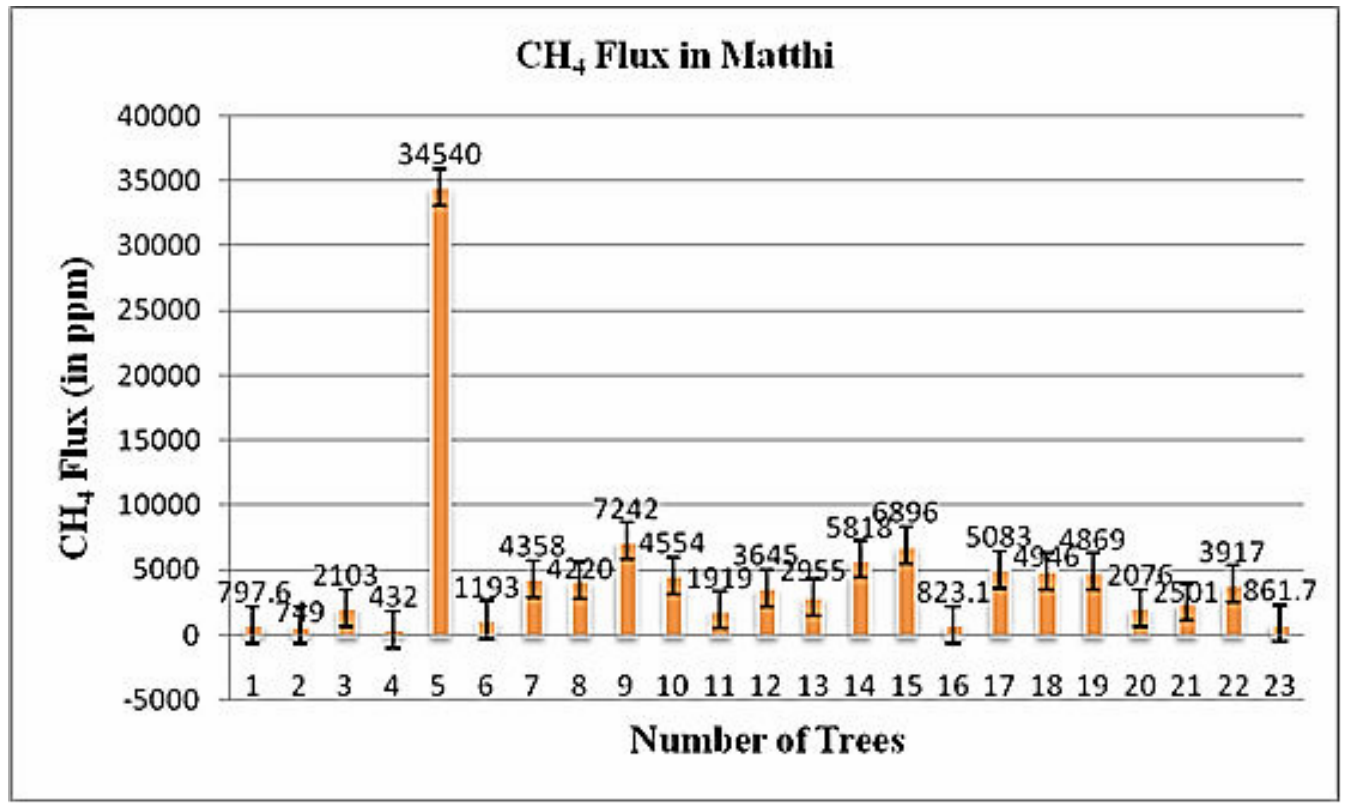

Fig.6 Box and whisker plot showing distribution of methane flux between species

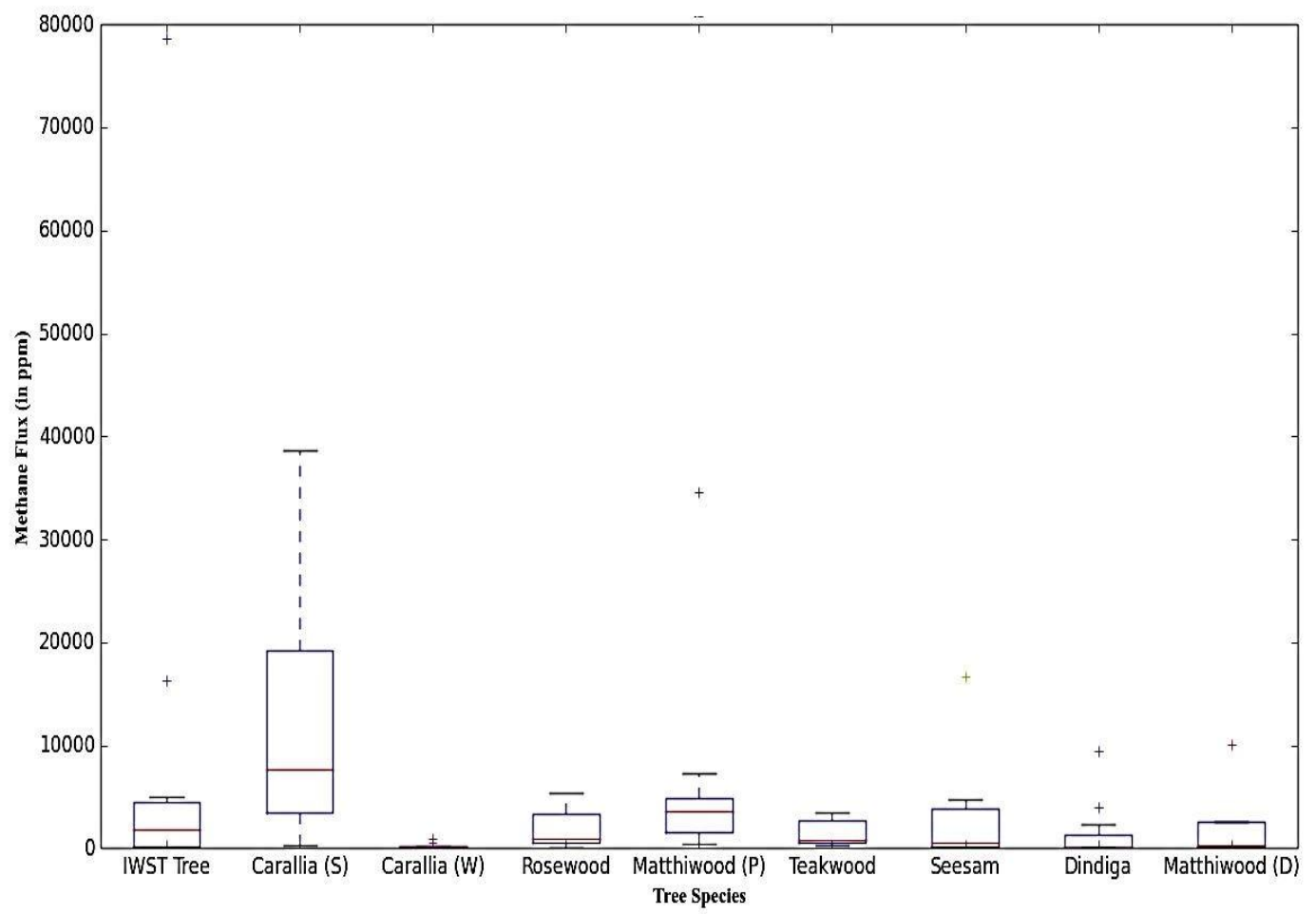


The GC analysis of Dalbergia sisso showed the highest $\mathrm{CH} 4$ emission observed was 16680 ppm (24 hours) and the lowest emission recorded was 1.677 ppm (2 hours).

\section{Box and whisker Plot}

Box plot is a convenient way of graphically depicting groups of numerical data through their quartiles. Box plots may also have lines extending from the boxes (whiskers) indicating variability outside the upper and lower quartiles. Box and whisker plot showing distribution of methane flux from species to species. $\mathrm{CH} 4$ emission in the dead trees of Carallia brachiata species displayed a strong seasonal variation (Fig. No. 6). Box plots are non-parametric, they display variation in samples of a statistical population. The spacing between the different parts of the box indicates the degree of dispersion (spread) and skewness in the data.

Various methods have been reported for quantification of $\mathrm{CH} 4$ emission from tree sources. Terazawa et al., (2007) used a steel chamber that was placed on the tree stem and gas samples were extracted from the chamber in intervals of 10 to $60 \mathrm{~min}$ and the $\mathrm{CH} 4$ contents of the gas samples were measured to extrapolate $\mathrm{CH} 4$ flux. The first experimental research paper published in the field of anaerobic $\mathrm{CH} 4$ emission in dead trees by Covey et al., (2012), where he argued that $\mathrm{CH} 4$ flux could be extrapolated from concentrations of $\mathrm{CH} 4$ measured in core samples especially on trees with uneven bark, this technique is much similar than measuring fluxes. Henceforth, careful considerations were taken at each step of the process ensuring reliable results as an outcome during our modified methodology for sampling gas from dead trees. Some of the factors that determine the quantity of methane were depth of the drill and incubation period. When the incubation period increases the quantity of methane estimated was also the highest. It is now six years (the period of this study - 2018) since Covey et al., (2012) reported anaerobic $\mathrm{CH} 4$ emission from dead tree. Our data suggest that dead trees in the forest contribute significantly to global $\mathrm{CH} 4$ emission. The $\mathrm{CH} 4$ concentration from six tree species viz., Carallia brachiata, Dalbergia sissoo, Terminalia tomentosa, Tectona grandis, Dalbergia sissoo and Anogeissus latifolia from different agro climatic zones of Karnataka were estimated. The maximum mean CH4 flux of $11976.73 \mathrm{ppm}$ was observed in Carallia brachiata, while the minimum of 1470.77 ppm was observed in Anogeissus latifolia. Therefore in addition to existing facts, it is once again proven that dead trees in forests are significant producers of $\mathrm{CH} 4$ gas. The present work was executed in tropical and sub-tropical forests of India. Our standardized method for $\mathrm{CH} 4$ gas extraction from dead trees was found effective. In connection to present change in climate pattern and subsequent effect on forest health, similar studies could be minimum significance in global warming prediction.

\section{Acknowledgement}

We thank the Director, Institute of Wood Science and Technology, Bangalore for providing necessary facilities and Karnataka Forest Department for funding the research work.

\section{References}

Bawa, K. S., and S. Dayanandan, Causes of tropical deforestation and institutional constraints to conservation: In Goldsmith, F.B (ed.) Tropical Rain Forest-a wider perspective. Conservation Biology Series. Chapman and Hall, Landon, (1998) 175-198. 
Covey, K. R., S. A. Wood, R. J. Warren, Ii, X. Lee, and M. A. Bradford, Elevated methane concentrations in trees of an upland forest. Geophys. Res. Lett. (2012) 39.

Dlugokencky, D. J., L. Bruhwiler, J. W. C. White, L. K. Emmons, P. C. Novelli, S. A. Montzka, K. A. Masarie, P. M. Lang, A. M. Crotwell, J. B. Miller, and L. V. Gatti, Observational constraints on recent increases in the atmospheric $\mathrm{CH} 4$ burden, Geophys. Res. Lett. (2009) 36: 30 L18803.

Dlugokencky, E. J., S. Houweling, L. Bruhwiler, K. A. Masarie, P. M. Lang, J. B. Miller, and P. P. Tans, Atmospheric methane levels off: temporary pause or a new steady-state? Geo-phys. Res. Lett. (2003) 30: 1992.

Etheridge, D. M, L. P. Steele, R. J. Francey, and R. L. Langenfelds, Atmospheric methane between 1000 A. D., and present: evidence of anthropogenic emissions and climatic variability, $J$. Geophys. Res. (1998) 103: 1597915993.

Harth, M., J. Mühle, and L. W. Porter, Renewed growth of atmospheric5 methane, Geophys. Res. Lett., 35, L22805.

Jones, R. L., and J. A. Pyle, Observations of $\mathrm{CH} 4$ and $\mathrm{N} 2 \mathrm{O}$ by the Nimbus-7 SAMS: a comparison with in-situ data and two-dimensional numerical model calculations, J. Geophys. Res. (1984) 89: 5263-5279.

Keppler, F., J. T. Hamilton, M. Brass, and T. Rockmann, Methane emissions from terrestrial plants under aerobic conditions, Nature, (2006) 439: 18791.

Kirschke, R., P. Bousquet, P. Ciais, M. Saunois, J. G. Canadell, E. J. Dlugokencky, P. Bergamaschi, D. Bergmann, D. R. Blake, L. Bruhwiler, P. Cameron-Smith, S. Castaldi, F.
Chevallier, L. Feng, A. Fraser, M. Heimann, E. L. Hodson, S. Houweling, B. Josse, P. J. Fraser, Krummel, P. B., J. F. Lamarque, R. L. Langenfelds, C. Le Quere, V. Naik, S. O'Doherty, P. I. Palmer, I. Pison, D. Plummer, B. Poulter, R. G. Prinn, M. Rigby, B. Ringeval, M. Santini, M. Schmidt, D. T. Shindell, I. J. Simpson, R. Spahni, L. P. Steele, S. A. Strode, K. Sudo, S. zopa, Van der Werf, G. R., A. Voulgarakis, M. van Weele, R. F. Weiss, J. E. Williams, and G. Zeng, Three decades of global methane sources and sinks, Nat. Geosci. (2013) 6: 813-823.

Loulergue, K., A. Schilt, R. Spahni, V. Masson-Delmotte, T. Blunier, B. Lemieux, J. M. Barnola, D. Raynaud, T. F. Stocker, and J. Chappellaz, Orbital and millennial-scale features of atmospheric $\mathrm{CH} 4$ over the past 800,000 years, Nature, (2008) 453: 383-386.

MacFarling Meure, C., D. Etheridge, C. Trudinger, P. Steele, R. Langenfelds, T. van Ommen, A. Smith, and J. W. Elkins, Law Dome $\mathrm{CO} 2, \mathrm{CH} 4$ and N2O ice core records extended to 2000 years BP, Geophys. Res. Lett. (2006) 33: L14810.

Myhre, F., D. Shindell, F. M. Bréon, W. Collins, J. Fuglestvedt, J. Huang, D. Koch, J. F. Lamarque, D. Lee, B. Mendoza, T. Nakajima, A. Robock, G. Stephens, T. Takemura, and H. Zhang, Anthropogenic and natural radiative forcing, in: Climate Change 2013: The Phys- ical Science Basis, Fifth Assessment Report of the Intergovernmental Panel on Climate Change, edited by: T. F. Stocker, et al., Cambridge University Press, Cambridge, UK, New York, NY, USA, (2013) 659-740.

Nakazawa, T., T. Machida, M. Tanaka, Y. 
Fujii, S. Aoki, and O. Watanabe, Differences of the atmospheric $\mathrm{CH} 4$ concentration between the Arctic and Antarctic regions in pre-industrial/preagricultural era, Geophys. Res. Lett. (1993) 20: 943-946.

Patra, P. K., S. Houweling, M. Krol, P. Bousquet, D. Belikov, D. Bergmann, H. Bian, P. Cameron-Smith, M. P. Chipperfield, K. Corbin, A. Fortems Cheiney, A. Fraser, E. Gloor, P. Hess, A. Ito, S. R. Kawa, R. M. Law, Z. Loh, S. Maksyutov, L. Meng, P. I. Palmer, R. G. Prinn,

Rasmussen, R. A., and M. A. K. Khalil, Atmospheric methane in the recent and ancient atmospheres: concentrations, trends, and interhemispheric gradient, J. Geophys. Res. (1984) 89: 11599-11605.
Rigby, K., R. G. Prinn, P. J. Fraser, P. G. Simmonds, R. L. Langenfelds, J. Huang, D. M. Cun- nold, L. P. Steele, P. B. Krummel, R. F. Weiss, S. O'Doherty, P. K. Salameh, H. J. Wang, C.

Rigby, M., R. Saito, and C. Wilson, TransCom model simulations of $\mathrm{CH} 4$ and related species: linking transport, surface flux and chemical loss with $\mathrm{CH} 4$ variability in the troposphere and lower stratosphere, Atmos. Chem. Phys. (2011) 11: 12813-12837.

Terazawa. K., S. Ishizuka, T. Sakatac, K. Yamada, and M. Takahashi, Methane emissions from stems of Fraxinus mandshurica var. japonica trees in a floodplain forest, Soil Biol. \& Biochem. (2007) 39: 2689-2692.

\section{How to cite this article:}

Muthu Kumar, A., R. Ezhumalai, A. K. Pandey and Srinivasa Rao, M. 2021. Emission of Methane from Dead Trees / Snags of Tropical and Sub-Tropical Forest Ecoregions. Int.J.Curr.Microbiol.App.Sci. 10(05): 418-428. doi: https://doi.org/10.20546/ijcmas.2021.1005.049 